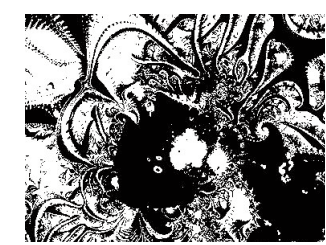

\title{
EFFECTS OF (MIS)ALIGNMENT BETWEEN SUPERVISORY AND ORGANIZATIONAL JUSTICE
}

Ana JAKOPEC

Faculty of Humanities and Social Sciences, Osijek

Zoran SUŠANJ

Faculty of Humanities and Social Sciences, Rijeka

UDK: 658.013

Izvorni znanstveni rad

Primlieno: 20. 3. 2014.

This article is a part of the research project "Determinants and effects of organizational (in) justice" (No. 13.04.1.4.21) supported by the University of Rijeka.

This study aimed to verify the interactive effects of supervisory and organizational justice on supervisory (satisfaction with supervisor and trust in leadership) and organization-oriented outcomes (perceived psychological contract fulfillment and organizational citizenship behavior). The results of combined polynomial regression with response surface methodology confirmed that the positive interaction effects of justice sources on all measured outcomes are the most pronounced in situations when employees perceive treatment from both sources as fair. However, the effects of the degree and direction of misalignment between sources of justice reflect variously, given the observed outcomes and justice types. Interestingly, if one source is seen as fair and the other as unfair, most often it results in a more negative outcome than in a situation when both sources are perceived as unfair, regardless of target similarity. The obtained results highlight the need for increasing the congruence between organizational systems and supervisors' activities in human resource management processes.

Keywords: multi-foci justice misalignment, distributive, procedural and interactional justice

$\square \quad$ Ana Jakopec, Josip Juraj Strossmayer University of Osijek, Faculty of Humanities and Social Sciences, Department of Psychology, L. Jägera 9, 31000 Osijek, Croatia. 
People in different life roles want to be treated fairly, especially in their workplace. Fairness in the organizational context refers to the employee's perceptions of justice in organizations along with their behavioral, cognitive and emotional reactions (Greenberg, 2011). Organizational justice involves three different elements: distributive, procedural and interactional. Distributive justice relates to the rules applied by employees to determine the fairness of outcomes distribution (Cropanzano \& Folger, 1989). This includes rules of equity (Adams, 1965), equality, and need (Deutsch, 1975; Leventhal, 1976). Procedural justice relates to the fairness of procedures used to define those outcomes. Those procedures should be consistent, unbiased, accurate, correctable, representative and morally acceptable (Leventhal, 1976). Interactional justice assumes the fairness of interpersonal treatment relating to the organizational procedures (McDowall \& Fletcher, 2004). It involves the way of communicating the information (accurate, sincere and thorough explanations for decisions made) and whether the individuals influenced by a decision were treated with politeness, dignity and respect (Bies \& Moag, 1986).

Traditionally, researchers have studied the employee's individual perceptions of justice and their effects on individual outcomes. Those individual level justice perceptions are related to a broad range of organizationally important outcomes: attitudes towards job, leaders and organization, motivation and performance at work, organizational citizenship and counterproductive behavior, stress and mental health (e.g., Bartle \& Hays, 1999; Cohen-Charash \& Spector, 2001; Colquitt, Conlon, Wesson, Porter, \& Ng, 2001; Cropanzano, Byrne, Bobocel, \& Rupp, 2001).

Also, it has been shown that employees not only consider the different types of justice (i.e., distributive, procedural, and interactional) but also consider the agent or source of the situation that is perceived as (un)fair (Cropanzano et al., 2001; Lavelle, Rupp, \& Brockner, 2007; Rupp \& Cropanzano, 2002). Multiple sources of justice have been studied within this area, including supervisors (Liao \& Rupp, 2005; Masterson, Lewis, Goldman, \& Taylor, 2000), the organization as a whole (Colquitt \& Shaw, 2005; Rupp \& Cropanzano, 2002), co-workers (Colquitt, 2004; Donovan, Drasgow, \& Munson, 1998), and customers (Rupp, McCance, Spencer, \& Sonntag, 2008; Wang, Liao, Zhan, \& Shi, 2011). Multi-foci perspective is deeply rooted in social exchange theory (Blau, 1964). In addition, Lavelle and colleagues' (2007) target similarity model argues that employees may also hold unique and multiple social exchange relationships with different sources of justice. The model as- 
DRUŠ. ISTRAŽ. ZAGREB GOD. 23 (2014), BR. 4 STR. 615-637

JAKOPEC, A., SUŠANJ, Z.: EFFECTS OF.. sumes that when treated fairly by a particular source, a social exchange relationship may develop between the employee and that exact source. Furthermore, attitudes and behavioral reactions are formed not in a general way, but with reciprocity, back toward the source. Thus, supervisory justice perceptions would be expected to be more predictive of satisfaction with one's supervisor and organizational citizenship behaviors directed at the supervisors, than global satisfaction/citizenship, or attitudes/behaviors directed at a different source (Rupp \& Paddock, 2010).

Furthermore, recent meta-analysis results (Rupp, Shao, Jones, \& Liao, 2014) showed that structuring justice by source (the supervisor and the organization) could explain more variance in employee attitudes and behaviors directed toward the source than does structuring by justice type. Moreover, this study gave support to the target similarity model, showing that social exchange with a source mediates multi-foci effects.

Multi-foci research and theory focus on main and mediating effects of different sources of justice on employee reactions. As such, little is known about the potential for joint, interactional effects of different sources on employee attitudes and behaviors. There are barely a few recent studies that explicitly examined the possibility of those effects (Lavelle, Rupp, Manegold, \& Thorton, in press). For example, Price, Lavelle, Henley, Cocchiara, and Buchanan (2006) found that it only took one source acting unfairly at any stage of a decision process to negatively influence following reactions. Rupp, Bashshur, and Liao (2007) presented evidence of an adverse effect of misalignment between supervisory and organizational justice climate on employees' reactions. According to Rupp et al. (2014), the possibility of detected multi-foci interactive effects is intriguing and the literature could benefit from more research in this area.

In line with that, the aim of this study is to verify the interactive (cross-foci) effects of supervisory and organizational (distributive, procedural and interactional) justice on different outcomes: supervisory satisfaction, trust in leadership, perceived psychological contract fulfillment and organizational citizenship behavior directed towards organization.

Supervisory satisfaction and trust in leadership have both been considered as supervisor-related outcomes. They should primarily depend on supervisory justice as compared to organizational justice, due to the target similarity model. Research has found that perceptions of supervisory justice predict satisfaction with supervision (e.g., Liao \& Rupp, 2005; Masterson et al., 2000). Also, studies on building trust in the supervisor 
DRUŠ. ISTRAŽ. ZAGREB GOD. 23 (2014), BR. 4, STR. 615-637

JAKOPEC, A., SUŠANJ, Z.: EFFECTS OF. show that justice perceptions are a significant factor in this process (Aryee, Budhwar, \& Chen, 2002; DeConinck, 2010). Furthermore, psychological contract fulfillment and organizational citizenship behavior toward the organization are both considered as organization-related outcomes. Therefore, they should in a larger extent depend on organizational justice. Perceptions of organizational justice are considered as an important factor for the experience of the psychological contract breach (e.g., Epitropaki, 2013; Morrison \& Robinson, 1997), as well as for employees' drift to engage in OCB (Cohen-Charash, \& Spector, 2001; LePine, Erez, \& Johnson, 2002).

According to our knowledge, interactive effects of different sources of justice on employees' trust in leadership and their estimation of the psychological contract fulfillment have not been investigated yet. Neither have the interactive effects of multi-foci types of justice (i.e. distributive, procedural and interactional) on these four outcomes been considered simultaneously.

First, we propose that the prediction of all the outcomes (either in a positive or negative direction), will be the most pronounced when the perceptions of (distributive, procedural and interactional) justice coming from different sources (supervisor and organization) are aligned (both of them entirely fair or unfair).

Justification for this hypothesis can be gathered from the theory of congruence in organizational research: studies of $\mathrm{P}-\mathrm{O}$ fit (e.g., Edwards, 1994), performance ratings (e.g., Johnson \& Ferstl, 1999), or supervisory vs. organizational support (e.g., Aselage \& Eisenberger, 2003). For example, researches have shown the theoretical value of perceived incongruence between supervisory and organizational support. Employees could have difficulties bonding with an organization when they are uncertain whether the supervisor and organization will show consistency in support, including which behaviors they might reward and value (Aselage \& Eisenberger, 2003). Also, in the framework of organizational justice literature, consistency of justice types (within the same foci) is found to be meaningful. Studies have shown that the strongest negative reactions to injustice occur when the individual perceives both unfair outcomes (distributive injustice) and unfair procedures (procedural injustice), while the strongest positive reactions most likely occur when outcomes and procedures are both seen as fair (Brockner \& Wiesenfeld, 1996; Folger \& Konovsky, 1989; Skarlicki \& Folger, 1997).

Second, based on the target similarity model, we propose that supervisor oriented outcomes (supervisory satisfaction and trust in leadership) will be more sensitive to supervisory (distributive, procedural and interactional) justice, while or- 
ganization oriented outcomes (psychological contract fulfillment and organizational citizenship behavior toward organization) will be more related to organizational justice.

METHOD

Participants

\section{Instruments}

Data was collected from a convenient sample of 673 employees, recruited from 32 Croatian organizations that represent a variety of diverse industries (e.g., public and private sector, manufacturing, service), departments (e.g., accounting, production, personnel), and organizational levels [e.g., ranging from workers $(48 \%)$, experts (33\%), first-line supervisors $(11 \%)$ to middle managers $(8 \%)]$. The gender composition of the sample was $42 \%$ male and $58 \%$ female. Slightly more than $70 \%$ of the employees are in the category up to 50 years of age, and the vast majority of participants ( $86 \%$ ) has more than five years of work experience in the current organization.

\section{Multi-foci justice measure}

Multi-foci justice measure (Jakopec \& Sušanj, 2014) was used to assess employees' perceptions of (distributive, procedural and interactional) justice in the workplace, taking into account the source of perceived fairness (the superior manager and the organization as a whole). The questionnaire contains a total of 30 items, of which 15 items intended to measure supervisory distributive, procedural and interactional justice and the same 15 items (with the variation of justice source only) were used to measure three organizational justice dimensions. Within each source, five items measured each of the three justice dimensions. Items were presented in Likert-type format with a scale ranging from 1 (completely disagree) to 5 (completely agree). Six models were tested and compared within confirmatory factor analysis in order to determine the best-fitting one. Results of CFA confirmed that the most appropriate model is the one that consists of six latent factors, which means that it takes into account the three-dimensionality of both justice sources $\left(\chi^{2}[\mathrm{df}=390 ; \mathrm{N}=673]=1200.9, \mathrm{p}<0.001 ; \mathrm{NC}=3.1\right.$; $\mathrm{CFI}=0.94 ; \mathrm{TLI}=0.93 ; \mathrm{AGFI}=0.94 ; \mathrm{NFI}=0.92 ; \mathrm{PGFI}=0.77$; RMSEA $=0.06$; AIC $=1410.9$ ). Composite scores were defined as mean values of all item estimations for each justice dimension, with higher scores indicating higher perceived supervisory/organizational justice for each of the three justice types. Cronbach's alpha coefficients for the three types of perceived supervisory justice were 0.93 for distributive (PSJ-D), 0.88 for procedural (PSJ-P), and 0.89 for interactional justice (PSJ-I). Cronbach's alpha coefficients for the three types of perceived 
DRUŠ. ISTRAŽ. ZAGREB GOD. 23 (2014), BR. 4, STR. 615-637

JAKOPEC, A., SUŠANJ, Z.: EFFECTS OF.. organizational justice were 0.90 for distributive (POJ-D), 0.84 for procedural (POJ-P), and 0.87 for interactional justice (POJ-I). An example of items are My supervisor/organization rewards me fairly given the effort I put in my work for supervisory/organizational distributive justice; My supervisor/organization uses objective procedures when evaluating my job performance for supervisory/ organizational procedural justice and My supervisor/organization respects me for supervisory/organizational interactional justice.

\section{Supervisory satisfaction}

Supervisory satisfaction, a 6 item subscale, adjusted from Gregson's (1987) Job satisfaction questionnaire, was used to assess employees' supervisory satisfaction (SS). Items were presented in Likert-type format with a scale ranging from 1 (completely disagree) to 5 (completely agree). Composite score was defined as a mean value of all 6 item estimations, with a higher score indicating higher supervisory satisfaction. Cronbach's alpha coefficient for supervisory satisfaction was 0.79 . An example of items is My superior does his job well.

\section{Trust in leadership}

Trust in leadership (adjusted from Marlowe \& Nyhan, 1992) was used to measure subordinates' trust in their supervisor (TL). The scale contains 7 items, presented in Likert-type format with a scale ranging from 1 (completely disagree) to 5 (completely agree). Composite score was defined as a mean value of all 7 item estimations, with a higher score indicating higher trust in leadership. Cronbach's alpha coefficient for trust in leadership was 0.89. An example of items is My supervisor can make good decisions and judgments.

\section{Psychological contract fulfillment}

Psychological contract fulfillment (scale adjusted from Robinson, Kraatz, \& Rousseau, 1994) was used to assess employees' estimation of the psychological contract fulfillment (PCF). The scale contains 7 items, presented in Likert-type format with a scale ranging from 1 (completely disagree) to 5 (completely agree). Composite score was defined as a mean value of all 7 item estimations, with a higher score indicating higher estimation of the psychological contract fulfillment. Cronbach's alpha coefficient for psychological contract fulfillment was 0.77 . An example of items is My employer provided me a high pay.

\section{Organizational citizenship behavior}

Organizational citizenship behavior (adjusted from Coleman \& Borman (2000) Organizational Citizenship Performance scale) was used to assess employees' organizational citizenship behavior towards organization (OCB-O). The scale contains 12 
DRUŠ. ISTRAŽ. ZAGREB GOD. 23 (2014), BR. 4 STR. 615-637

JAKOPEC, A., SUŠANJ, Z.: EFFECTS OF.. items, presented in Likert-type format with a scale ranging from 1 (completely disagree) to 5 (completely agree). Composite score was defined as a mean value of all 12 item estimations, with a higher score indicating higher employees' organizational citizenship behavior towards the organization. Cronbach's alpha coefficient for organizational citizenship behavior towards the organization was 0.79 . An example of items is I was promoting and defending my organization.

\section{Procedure and analysis}

The research was conveyed in larger or smaller groups at the employee's organization. It lasted about 30 minutes. Participation in the study was voluntary and anonymous. Data was analyzed using a combined polynomial regression and response surface method approach. The step-by-step procedure suggested by Shanock, Baran, Gentry, Pattison, \& Heggestad $(2010,2014)$ was strictly followed and applied: we (1) inspected how many participants have discrepancies between the two predictors, (2) ran polynomial regression in SPSS and calculated the surface values (details are presented in the Note of Table 3), (3) graphed the results in Excel and finally (4) interpreted the surface values and graph.

We applied common form of the equation to test for relationships using polynomial regression:

$$
\mathrm{Z}=\mathrm{b}_{0}+\mathrm{b}_{1} \mathrm{X}+\mathrm{b}_{2} \mathrm{Y}+\mathrm{b}_{3} \mathrm{X}^{2}+\mathrm{b}_{4} \mathrm{XY}+\mathrm{b}_{5} \mathrm{Y}^{2}+\mathrm{e} \text {; }
$$

where $\mathrm{Z}$ is the outcome variable, $\mathrm{X}$ is first predictor (PSJ dimension in this case), and $\mathrm{Y}$ is the second predictor (POJ dimension in this case). Rather than directly interpreting the results from the polynomial regression analysis, the coefficients from the analysis are used to consider what is named the "response surface pattern" (Edwards, 1994; Shanock et al., 2010,2014 ) which is graphed to produce a three-dimensional visual representation of the data to support the interpretation, as suggested by Shanock et al. $(2010,2014)$.

We used SPSS Syntax and Excel spreadsheet provided from authors (Shanock et al., 2010, 2014) for calculating and graphing the results.

\section{RESULTS}

\section{Descriptive statistics and correlations}

The descriptive statistics and bivariate correlations for all variables measured are shown in Table 1.

As expected, the correlations between all predictor and outcome variables were moderately to highly positive and significant, although the correlations between supervisory and organizational (distributive, procedural and interactional) justice and OCB-O were lower comparing to other outcome variables. 
(1) TABLE 1

Means, standard

deviations, Cronbach

alpha coefficients and

correlations of all

variables measured

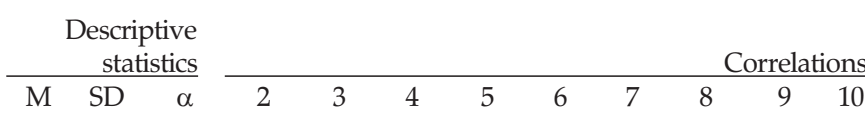

1 Distributive supervisory justice

2 Procedural supervisory justice

3 Interactional supervisory justice

4 Distributive organizational justice

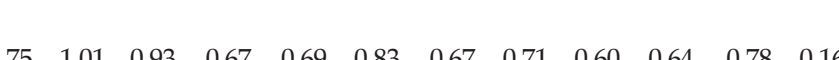

Procedural organizational justice

$\begin{array}{llllllllllll}3.17 & 0.92 & 0.88 & - & 0.85 & 0.63 & 0.80 & 0.76 & 0.78 & 0.81 & 0.66 & 0.28\end{array}$

$3.23 \quad 0.95 \quad 0.89$

$\begin{array}{llllllll}- & 0.61 & 0.76 & 0.78 & 0.78 & 0.82 & 0.66 & 0.28\end{array}$

$\begin{array}{lll}2.74 & 0.99 \quad 0.90\end{array}$

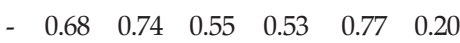

Interactional organizational justice

$\begin{array}{lll}3.09 & 0.82 \quad 0.84\end{array}$

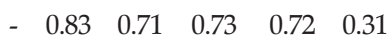

Supervisory satisfaction

$\begin{array}{lll}3.05 & 0.89 & 0.87\end{array}$

$\begin{array}{lll}3.16 & 0.82 & 0.79\end{array}$

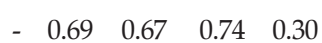

8 Trust in leadership

$\begin{array}{lll}3.45 & 0.83 & 0.89\end{array}$

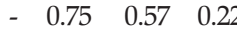

9 Psychological contract fulfillment

10 OCB towards organization

$\begin{array}{lll}3.89 & 0.52 & 0.79\end{array}$

$\mathrm{N}=673$, all correlations are significant at $\mathrm{p}<0.01$

\section{Descriptive information about the occurrence of justice discrepancies}

Frequencies of the perceived supervisory justice (PSJ) levels over, under, and in agreement with perceived organizational

(1) TABLE 2

Frequencies of perceived supervisory justice (PSJ) levels over, under, and in agreement with perceived organizational justice (POJ) levels justice (POJ) levels for all justice types are presented in Table 2. More than $30 \%$ of the sample has values of each type of PSJ and POJ that are diverse from each other in one direction or the other which is more than the satisfying $10 \%$ suggested by Shanock et al. (2010) to conclude that exploring how discrepancies between these justice sources related to outcome variables makes practical sense.

\begin{tabular}{|c|c|c|c|c|c|c|c|c|c|}
\hline \multirow[b]{2}{*}{ Agreement groups } & \multirow[b]{2}{*}{$\mathrm{D}$} & \multicolumn{2}{|c|}{ Percentage } & \multicolumn{3}{|c|}{$\begin{array}{c}\mathrm{M} \\
\text { (Supervisory) }\end{array}$} & \multicolumn{3}{|c|}{$\begin{array}{r}\mathrm{M} \\
\text { (Organizational) }\end{array}$} \\
\hline & & $\mathrm{P}$ & I & $\mathrm{D}$ & $\mathrm{P}$ & $\mathrm{I}$ & $\mathrm{D}$ & $\mathrm{P}$ & I \\
\hline PSJ more than POJ & 15.8 & 19.2 & 24.7 & 3.25 & 3.60 & 3.62 & 2.33 & 2.72 & 2.69 \\
\hline In agreement & 69.4 & 69.8 & 66.6 & 2.73 & 2.21 & 3.24 & 2.75 & 3.19 & 3.20 \\
\hline PSJ less than POJ & 14.9 & 11.0 & 8.8 & 2.32 & 2.20 & 2.07 & 3.18 & 3.05 & 3.05 \\
\hline
\end{tabular}

Note. $\mathrm{N}=673$. PSJ = perceived supervisory justice; $\mathrm{POJ}=$ perceived organizational justice; $\mathrm{D}=$ distributive; $\mathrm{P}=$ procedural; $\mathrm{I}=$ interactional.

\section{Results of polynomial regression and response surface analysis} sis for all outcome variables are presented in Table 3. 
DRUŠ. ISTRAŽ. ZAGREB GOD. 23 (2014), BR. 4, STR. 615-637

JAKOPEC, A., SUŠANJ, Z.: EFFECTS OF.. $\rightarrow$ TABLE 3

Effects of supervisory and organizational justice (mis)alignment on supervisory satisfaction, trust in leadership, perceived psychological contract fulfillment and $O C B$ towards organization

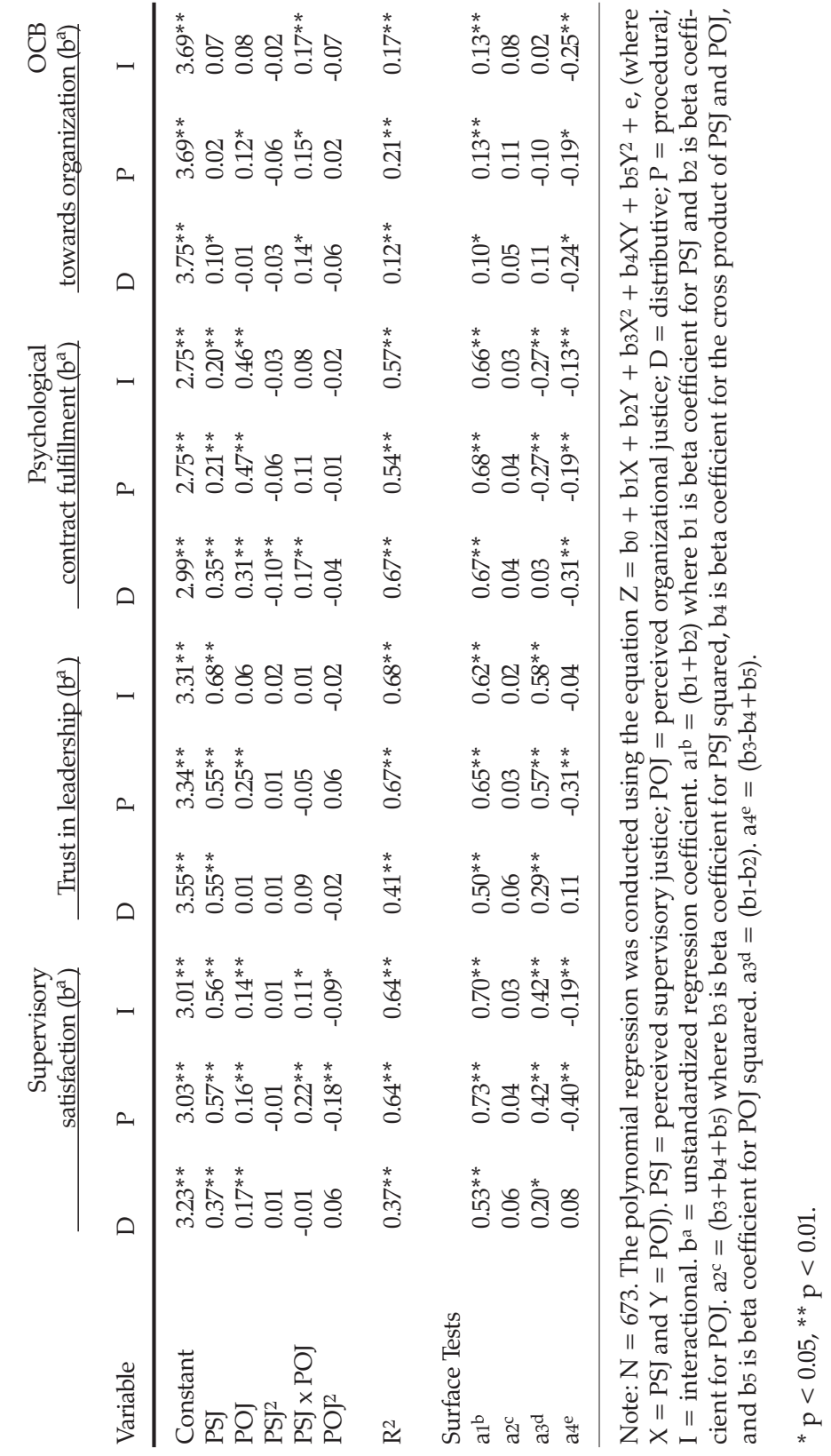

Because all types of PSJ and POJ are positively related to all outcome variables (OV), when PSJ and POJ are in agreement (i.e., employee's perceptions of each source of justice are at essentially the same level), a linear relationship is proposed. Thus, a significant positive slope of the line of perfect agreement (a1) along with a non-significant curvature along the line of perfect agreement (a2) as related to OV is expected. Further- 
DRUŠ. ISTRAŽ. ZAGREB STR. 615-637

JAKOPEC, A., SUŠANJ, Z.: EFFECTS OF.. GOD. 23 (2014), BR. 4,

more, when PSJ is greater than POJ or vice versa, it is expected that OV will be lower than when the two justice sources are in agreement and positive. More precisely, this proposition corresponds to an expectation of a significant negative curvature along the line of incongruence (a4) as it relates to OV. Additionally, due to target similarity effect (Lavelle et al., 2007), the direction of discrepancy may differentially affect OV. For example, PSJ may be more important than POJ to maintaining SS and TL because these attitudinal outcomes are directed toward the supervisor, not the organization itself. More precisely, this proposition corresponds to an expectation of a significant positive slope of the line of incongruence (a3) as it relates to SS and TL, and a significant negative slope of the line of incongruence (a3) as it relates to PCF and OCB-O.

Effects of justice sources (mis)alignment on each outcome will be individually clarified, due to the complexity of the results.

Effects of supervisory and organizational (distributive, procedural and interactional) justice (mis)alignment on supervisory satisfaction. Response surface plots are shown in Figure 1.

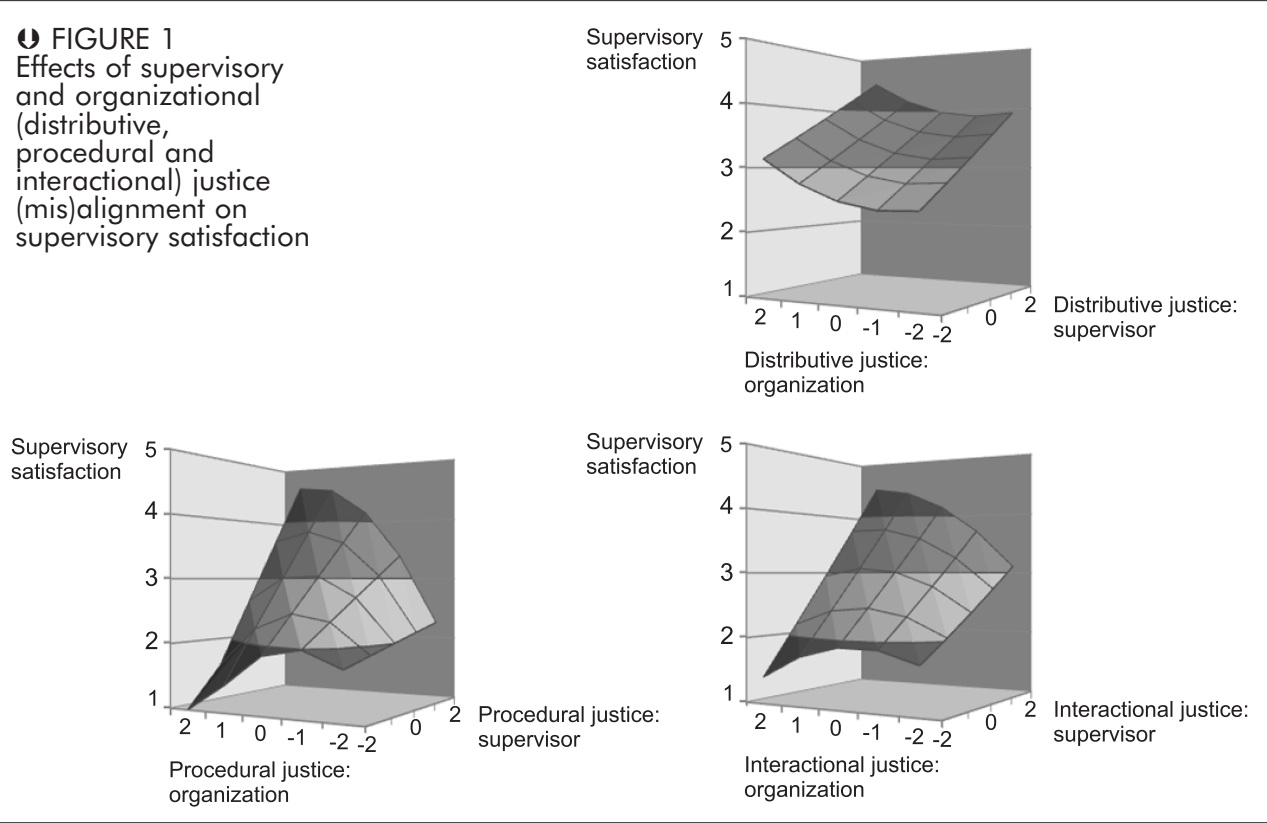

First surface plot in Figure 1 refers to the (mis)alignment of distributive justice perceptions coming from different sources. The surface tests resulted in a significant positive a1 value with a non-significant a2 value (see Table 3), suggesting that SS improved as POJ-D and PSJ-D increased. This finding indi- 
DRUŠ. ISTRAŽ. ZAGREB GOD. 23 (2014), BR. 4, STR. 615-637

JAKOPEC, A., SUŠANJ, Z.: EFFECTS OF.. in SS is enhanced by both sources of distributive justice in combination. The degree (a4) of discrepancy (misalignment) between PSJ-D and POJ-D in relation to the SS was insignificant, meaning that the degree of discrepancy did not matter. The significant and positive direction of discrepancy (a3) indicates that $S S$ is higher when the direction of the discrepancy is such that PSJ-D is higher than POJ-D than vice versa. SS levels decreased less when the discrepancy was such that PSJ-D was higher than POJ-D than when POJ-D was higher than PSJ-D.

Second and third surface plots in Figure 1 refer to the (mis)alignment of procedural and interactional justice perceptions coming from different sources. They have the same tendency of all a - value significance. Both surface plots resulted in a significant positive a1, insignificant a2, significant positive a3 and significant negative a4 values. Significant positive a1 values indicate that SS improved as PSJ-P and POJ-P, as well as PSJ-I and POJ-I increased. Significantly negative a4 values suggest that SS decreases more sharply as the degree of discrepancy between PSJ-P and POJ-P, and between PSJ-I and POJ-I, respectively, increases. The significant and positive direction of discrepancy (a3) indicates that SS is higher when the direction of the discrepancy is such that PSJ-P / PSJ-I is higher than POJ-P / POJ-I than vice versa.

Effects of supervisory and organizational (distributive, procedural and interactional) justice (mis)alignment on trust in leadership. Response surface plots are shown in Figure 2.

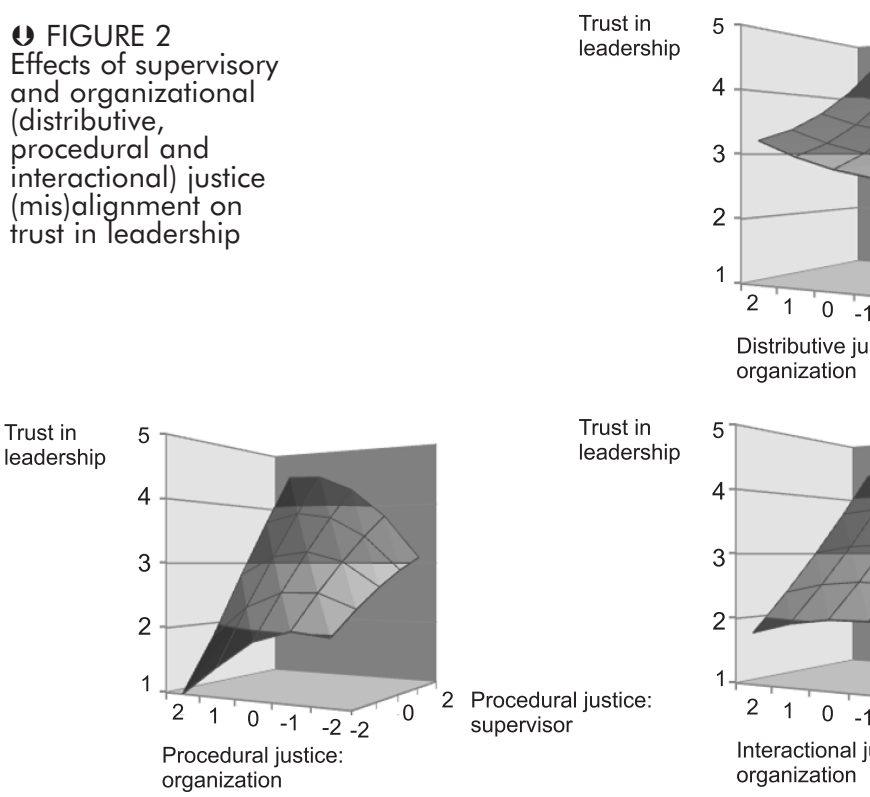

2 Procedural justice: Procedural justice: organization

Trust in organization 
DRUŠ. ISTRAŽ. ZAGREB GOD. 23 (2014), BR. 4, STR. 615-637

JAKOPEC, A., SUŠANJ, Z.: EFFECTS OF..
Regarding the TL, the surface tests resulted in significant positive a1 values with insignificant a2 values (see Table 3 ), in all three surface plots. These results suggest that TL is at the highest level when the perceptions of justice from both sources are aligned and positive. This accounts for all three types of justice perceptions. Also, all three surface plots have significant and positive as values, which means that TL is higher when the direction of the discrepancy is such that PSJ are higher than the POJ (than vice versa), regardless of justice type. Finally, only the surface plot which refers to the (mis)alignment of procedural justice perceptions coming from different sources, has a significant and negative at value. This suggests that TL decreases more sharply as the degree of discrepancy between PSJ-P and POJ-P increases.

Effects of supervisory and organizational (distributive, procedural and interactional) justice (mis)alignment on psychological contract fulfillment. Response surface plots are shown in Figure 3.

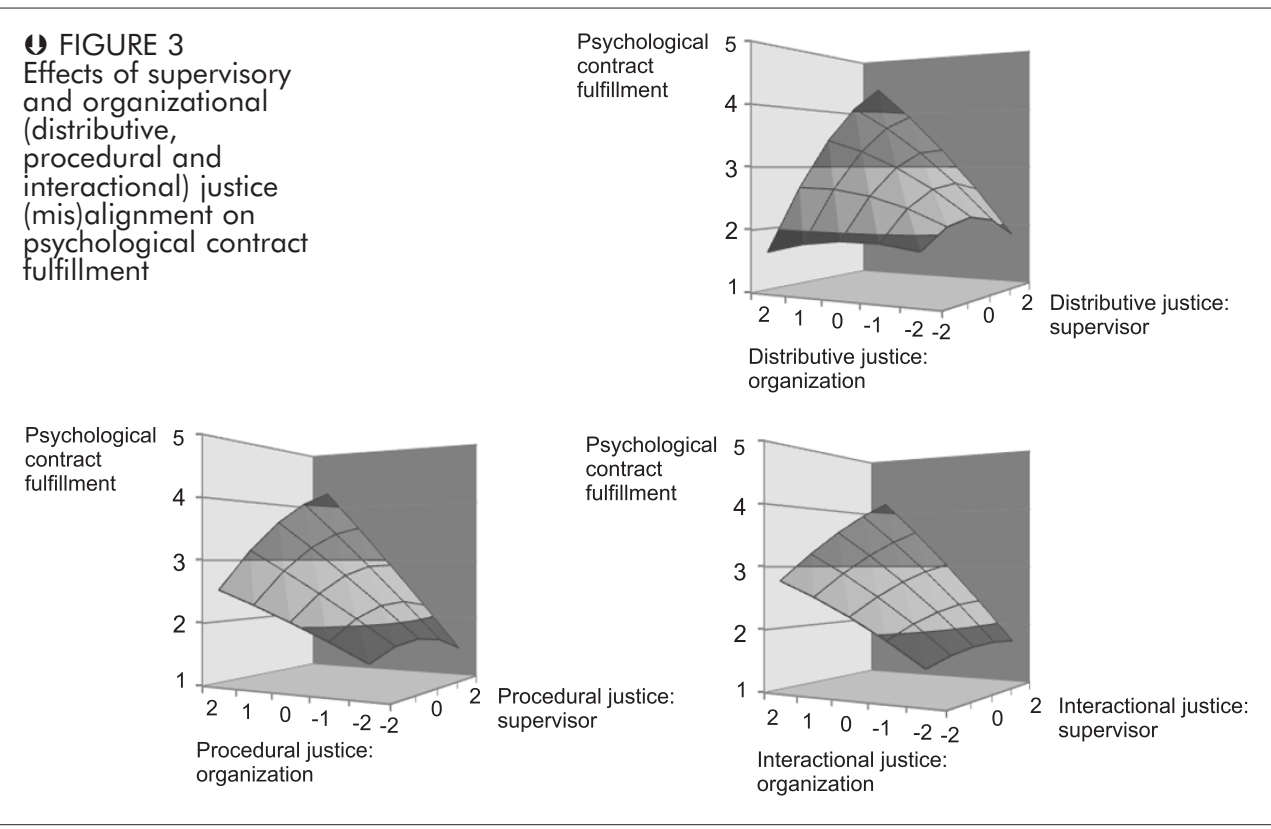

Figure 3 demonstrates the effects of supervisory and organizational (distributive, procedural and interactional) justice (mis)alignment on PCF. All three surface plot tests represented in Figure 3 resulted in a significant positive a1, insignificant a2, and significant negative a4 values. A significant positive a1, along with insignificant a2 values, suggest that PCF increases, as both POJ and PSJ increase. This applies to all justice types. Additionally, all surface plots have a significant and negative a4 value. This suggests that PCF decreases 
DRUŠ. ISTRAŽ. ZAGREB GOD. 23 (2014), BR. 4 STR. 615-637

JAKOPEC, A., SUŠANJ, Z. EFFECTS OF.. more sharply as the degree of discrepancy between justice sources increases. Besides that, when it comes to the perceptions of distributive justice, the direction of discrepancy does not matter as much (the slope of the line of incongruence (a3) is insignificant). However, in the case of procedural and interactional justice, the direction of discrepancy matters a lot - the slope of the line of incongruence (a3) is negative and significant. PCF is far more positive when the direction of the discrepancy is such that POJ is higher than PSJ (than vice versa).

Effects of supervisory and organizational (distributive, procedural and interactional) justice (mis)alignment on OCB towards organization. Response surface plots are shown in Figure 4.
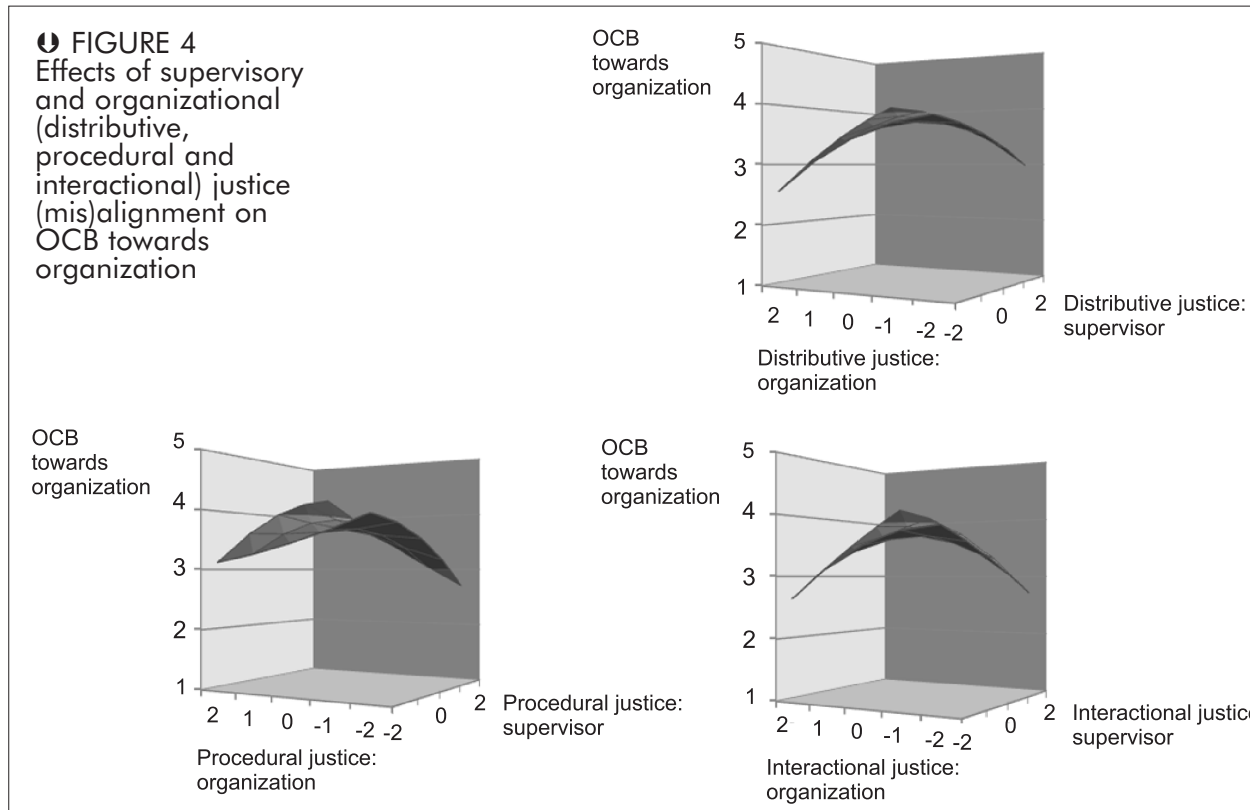

Figure 4 shows the effects of supervisory and organizational (distributive, procedural and interactional) justice (mis)alignment on OCB-O. Those three surface plots have the same tendency of value significance, which means that the results are consistent regardless of justice type. All of them resulted in a significant positive a1, insignificant a2, insignificant a3 and significant negative a4 values. A significant positive a1 with insignificant a2 values, suggest that OCB-O enhanced, as POJ and PSJ increased. OCB-O is at the highest level when justice perceptions of both sources are aligned and positive. However, when justice sources are both negative and aligned, OCB-O is approximately equally high as when justice sources are both positive and aligned. Additionally, all surface plots have the significant and negative a4 value. These 
DRUŠ. ISTRAŽ. ZAGREB GOD. 23 (2014), BR. 4, STR. 615-637

JAKOPEC, A., SUŠANJ, Z.: EFFECTS OF..

\section{DISCUSSION}

results suggest that OCB-O decreased more sharply, as the degree of discrepancy between perceptions of justice coming from different sources increased. At the same time, the direction of discrepancy does not matter as much (insignificant a3 in all three cases). OCB-O is at the lowest level when justice sources are misaligned.

This study aimed to contribute to the existing literature by clarifying the nature of interaction between two justice sources, with regard to the different dimensions of justice. It sought to verify the interactive effects of supervisory and organizational justice on supervisor and organization oriented outcomes. The results gave only partial support to the assumptions. Briefly, the results without exception confirm that the positive interaction effects of all three dimensions of justice, on all measured outcomes are most pronounced in situations when employees perceive treatment from both sources as fair. Nevertheless, the effects of the degree and direction of misalignment between organizational and supervisory justice reflect variously, given the observed outcomes and justice types.

The most relevant facet of job satisfaction for this study is the satisfaction with the supervisor. Our results indicate that employees are most unsatisfied with their supervisor when they perceive the allocation of the resources (i.e., distributive justice) as completely unfair from both sources simultaneously. The negative effects of misalignment between organizational and supervisory justice, when it comes to fairness of outcomes allocation, occur only when the supervisor's treatment is perceived as unfair, regardless of the fairness of the organization. Regarding the fairness of procedures and interpersonal treatment, employees are most unsatisfied with their supervisor, not in a situation when both sources are unfair, which was expected, but when the supervisor is perceived as completely unfair, regardless of the fairness of the organization. These findings are in line with the target similarity model (Lavelle et al., 2007). However, in the situation when the supervisor is perceived as completely fair while the organization is perceived as unfair, employees' satisfaction with him or her still significantly decreases, in comparison to the situation when both sources are perceived as fair, reducing the target similarity effect.

Trust is defined as a psychological state comprising a willingness to accept vulnerability based on positive expectations about the intentions or behavior of another (Rousseau, Sitkin, Burt, \& Camerer, 1998). Trust in supervisor has been shown to impact in-role behavior, which directly benefits the supervisor (Aryee et al., 2002). Studies showed that employ- 
DRUŠ. ISTRAŽ. ZAGREB GOD. 23 (2014), BR. 4 STR. 615-637

JAKOPEC, A., SUŠANJ, Z.: EFFECTS OF.. ees who trust their supervisors are more likely to display organizational citizenship behaviors (Konovsky \& Pugh, 1994), voluntarily accept supervisor's decisions and believe in the legitimacy of their decisions (Tyler, Degoey, \& Smith, 1996). Considering distributive and interactional justice, our results suggest that trust in leadership significantly decreases (and is the lowest) in situations when employees perceive the supervisors' allocation of outcomes or interpersonal treatment as unfair. However, when the supervisor is perceived as entirely fair, regardless of the level of organizational unfair treatment, employees' trust is still very high, almost as high as when both sources are perceived as fair, which gives strong support to the target similarity model. Nevertheless, when it comes to the fairness of procedures, things somewhat differ. Misalignment of justice sources negatively affects employees' evaluations of their supervisor. They show the lowest level of trust in the supervision when the supervisor is perceived as unfair while they simultaneously perceive the organization as fair, even lower than in the situation when both sources are perceived unfair, which is evidence of the target similarity effect. However, when supervisors' procedures are perceived as completely fair, and at the same time organizational procedures are perceived unfair, employees have significantly less trust in the supervisor as compared to the situation when both sources are fair. The psychological contract consists of the beliefs that employees hold regarding the conditions and terms of the exchange arrangement between themselves and their organizations (Robinson et al., 1994). Specifically, they are composed of obligations and promises that employees assume their organization owes them and obligations and promises the employees believe they owe their organization in return. When those promises are met, the psychological contract can be described as being fulfilled, which is certainly something to aim for. When an organization is meeting or exceeding the employee's expectations, it creates in them feelings of being valued and increases their trust. Employees in that case are more prone to return with actions, which aim to benefit the employee and the organization as a whole (Coyle-Shapiro \& Kessler, 2002; Robinson \& Morrison, 1995; Turnley, Bolino, Lester, \& Bloodgood, 2003). A psychological contract violation or breach exists when an employee perceives that the organization has failed to answer its obligations to him or her (Morrison \& Robinson, 1997). Relating the fairness of procedures and interpersonal treatment, the results of this study show that the degree of misalignment between two justice sources negatively affects employees' estimations of the psychological contract fulfillment, in both directions. However, the strongest negative estimations occur when procedures 
DRUŠ. ISTRAŽ. ZAGREB GOD. 23 (2014), BR. 4, STR. 615-637

JAKOPEC, A., SUŠANJ, Z.: EFFECTS OF.. and interpersonal treatment coming from the organization are perceived as unfair. With regard to the fairness of outcomes allocation (distributive justice), the direction of misalignment does not even matter; the negative effects of a misalignment degree are very pronounced. In this case, the target similarity effect disappears.

Organizational citizenship behavior refers to a variety of discretionary, extra-role behaviors that contribute to organizational effectiveness but are not explicitly required (e.g., LePine et al., 2002; Organ, 1997). Organ (1997) suggested that organizational citizenship behavior enhances the social and psychological context that supports task performance, and thus positively and indirectly contributes to organizational effectiveness. It was shown that employees meaningfully discriminate between the different targets when directing their citizenship behaviors (e.g., Karriker \& Williams, 2009; Williams \& Anderson, 1991). Hence, citizenship research often relies on the distinction between organizationally and interpersonally oriented citizenship behaviors (Williams \& Anderson, 1991). When it comes to the organization oriented organizational citizenship behavior in this study, the results show a surprising tendency across all justice types. The employees' drift to engage in organizational citizenship behavior towards the organization are almost the same (and very high), irrespective of whether both sources are perceived as fair, on unfair, as long as they are aligned. Misalignment of justice sources negatively affects employees' engagement in organizational citizenship behavior, regardless of the direction of misalignment, which is not consistent with the target similarity model.

In brief, the results gave only partial support to the target similarity model. In most cases, interactive effects of justice coming from different sources are very pronounced. These findings of powerful interactive effects are consistent with the results of previous research examining interactive effects of multi-foci justice (e.g., Price et al., 2006; Rupp et al., 2007), and with the P-O fit literature, as well. Also, Stapel and Koomen (2001) argued that a variety of social judgment models assert that both the interpretation of a perceived target stimulus and the comparison of this stimulus to a relevant standard are important components of person impression formation processes. Van den Bos (2002) extended Stapel and Koomen's (2001) interpretation/comparison model to the domain of organizational justice. He found that people in organizations sometimes compare the outcomes they have received to the procedures they have experienced. A result of this comparison may be that contrasting effects are found. Specifically, higher levels of procedural justice may lead to more negative, not more positive, reactions of employees. 
DRUŠ. ISTRAŽ. ZAGREB GOD. 23 (2014), BR. 4 STR. 615-637

JAKOPEC, A., SUŠANJ, Z.: EFFECTS OF..
Similarly, the results of our study show that when comparing different justice sources, the same contrasting effects may be found. As suggested by Rupp et al. (2007), these findings can be interpreted through the met expectations hypothesis (Wanous, Stumpf, \& Bedrosian, 1979). In the workplace, treatment from one source of justice shapes employee expectations for treatment from other sources. When treatment is negative across all sources, it becomes expected, and employees tolerate it. However, when treatment is incongruent, employees experience misalignment shock and react negatively, not only toward the source of injustice as suggested by Rupp et al. (2007), but often toward the other (even entirely fair) sources. It is also possible that employees' expected values (i.e. fair treatment) in the organization are a function of employees' personal values. The value percept disparity model (Locke, 1969) recognizes explicitly that employees hold their own values, and perceive values in organizations. Whether values are fulfilled, depends on the employees' cognitive-evaluative processes in which the perceived values of an organization are compared to one's own values. The smaller the disparity between the percept of the organization/supervisor's values and one's own values, the more favorable the evaluation becomes i.e. satisfaction increases (Westbrook \& Reilly, 1983). The same authors argue that employees seek attainment of values, rather than confirmation of their expectations. They found that desire for congruency contributes more to the positive outcomes than the disconfirmation of expectations standard. This might alternatively explain some of the above mentioned findings.

The present study has limitations, as well. First, the study design does not allow conclusions about the causal relationship between constructs, and it does not determine the process of their development and changes over time, so it raises the possibility of alternative interpretations of the results. Second, the average correlations among justice types, both within and between two sources were high. For this research question and analysis method, high correlations between two sources represent a larger issue, compared to those within the same source. However, despite the high intra-source correlations, surface plots regarding the same outcome variable but different justice types exhibit a (somewhat) different pattern and shape of the results. Nevertheless, measurement of (multi-foci) justice perceptions still represents an issue which should be addressed by forthcoming research. Also, it might have been difficult for participants to evaluate distributive justice, whilst they do not have information on comparable peer's pay (Hartmann \& Slapničar, 2012). Additionally, future research should consider controlling the amount of autonomy that supervisors have regarding the allocation of resour- 
DRUŠ. ISTRAŽ. ZAGREB GOD. 23 (2014), BR. 4, STR. 615-637

JAKOPEC, A., SUŠANJ, Z.: EFFECTS OF.

\section{REFERENCES}

ces. However, regardless of the aforementioned, participants definitely had their perception of distributive justice. Another limitation of the study could be the collection of the data from the same sources, at the same time, using the same (self-ratings) method. This brings up the issue of common method variance. Harman's single-factor test is a widely used technique for addressing the issue of common method variance (Podsakoff, MacKenzie, Lee, \& Podsakoff, 2003). An examination of the un-rotated factor structure of the variables was conducted, and the single-factor analysis revealed that no single factor accounted for the majority of the covariance. There were 10 factors that emerged with eigen values greater than one, accounting for $72 \%$ of the variance. The first factor accounted for $24 \%$ of the variance. A single factor did not emerge from the factor analysis, and one general factor did not account for the majority (more than 50\%) of the covariance among the measures (Podsakoff et al., 2003); therefore, it did not appear that common method variance represented a problem for this study. Regarding the convenient sample of employees, we also tested the measurement invariance of justice scales. The results of multi-group analysis within SEM indicated full metric invariance of justice scales, regarding employees' age, gender, level of education, work experience, hierarchical level in the organization and type of organization (public/private).

Finally, this study has some important practical implications, too. The perception of justice of only one source is simply not enough. Paradoxically, if one source is very fair while the other extremely unfair, it can result in a more negative effect than in a situation when both sources are unfair. If we consider different systems and processes of human resource management (appraising, rewarding, training, promoting and informing), organizations should strive not only to the perceptions of fairness, but also to the congruence of those systems and leaders' behavior. Hence, it is not enough just to develop fair systems and processes for managing people, but it is necessary that those systems and processes are also fairly and consistently implemented in practice by managers at all levels of the hierarchy.

Adams, J. S. (1965). Inequity in social exchange. In L. Berkowitz (Ed.), Advances in experimental social psychology (Vol. 2, pp. 267-299). New York: Academic Press.

Aryee, S., Budhwar, P. S., \& Chen, Z. X. (2002). Trust as a mediator of the relationship between organizational justice and work outcomes: Test of a social exchange model. Journal of Organizational Behavior, 23(3), 267-285. doi:10.1002/job.138 
DRUŠ. ISTRAŽ. ZAGREB GOD. 23 (2014), BR. 4 STR. $615-637$

JAKOPEC, A., SUŠANJ, Z.: EFFECTS OF...
Aselage, J., \& Eisenberger, R. (2003). Perceived organizational support and psychological contracts: A theoretical integration. Journal of Organizational Behavior, 24(5), 491-509. doi:10.1002/job.211

Bartle, S. A., \& Hayes, B. C. (1999). Organizational justice and work outcomes: A meta-analysis. In Annual meeting of the Society for Industrial and Organizational Psychology, Atlanta, GA.

Bies, R. J., \& Moag, J. F. (1986). Interactional justice: Communication criteria of fairness. In R. J. Lewicki, B. H. Sheppard, \& M. H. Bazerman (Eds.), Research on negotiations in organizations (Vol. 1, pp. 43-55). Greenwich, CT: JAI Press.

Blau, P. M. (1964). Exchange and power in social life. New York: Wiley.

Brockner, J., \& Wiesenfeld, B. M. (1996). An integrative framework for explaining reactions to decisions: Interactive effects of outcomes and procedures. Psychological Bulletin, 120(2), 189-208. doi:10.1037/ 0033-2909.120.2.189

Cohen-Charash, Y., \& Spector, P. E. (2001). The role of justice in organizations: A meta-analysis. Organizational Behavior and Human Decision Processes, 86(2), 278-321. doi:10.1006/obhd.2001.2958

Coleman, V. I., \& Borman, W. C. (2000). Investigating the underlying structure of the citizenship performance domain. Human Resource Management Review, 10(1), 25-44. doi:10.1016/S1053-4822(99)00037-6

Colquitt, J. A. (2004). Does the justice of the one interact with the justice of the many? Reactions to procedural justice in teams. Journal of Applied Psychology, 89(4), 633-646. doi:10.1037/0021-9010.89.4.633

Colquitt, J. A., Conlon, D. E., Wesson, M. J., Porter, C. O. L. H., \& Ng, K. Y. (2001). Justice at the millennium: A meta-analytic review of 25 years of organizational justice research. Journal of Applied Psychology, 86(3), 425-445. doi:10.1037/0021-9010.86.3.425

Colquitt, J. A., \& Shaw, J. C. (2005). How should organizational justice be measured? In J. Greenberg, \& J. A. Colquitt (Eds.), The handbook of organizational justice (pp. 113-152). Mahwah, NJ: Erlbaum.

Coyle-Shapiro, J. A.-M., \& Kessler, I. (2002). Exploring reciprocity through the lens of the psychological contract: Employee and employer perspectives. European Journal of Work and Organizational Psychology, 11(1), 69-86. doi:10.1080/13594320143000852

Cropanzano, R., Byrne, Z. S., Bobocel, D. R., \& Rupp, D. E. (2001). Moral virtues, fairness heuristics, social entities, and other denizens of organizational justice. Journal of Vocational Behavior, 58(2), 164-209. doi:10.1006/jvbe.2001.1791

Cropanzano, R., \& Folger, R. (1989). Referent cognitions and task decision autonomy: Beyond equity theory. Journal of Applied Psychology, 74(2), 293-299. doi:10.1037/0021-9010.74.2.293

DeConinck, J. B. (2010). The effect of organizational justice, perceived organizational support, and perceived supervisor support on marketing employees' level of trust. Journal of Business Research, 63 (12), 1349-1355. doi:10.1016/j.jbusres.2010.01.003

Deutsch, M. (1975). Equity, equality, and need: What determines which value will be used as the basis of distributive justice? Journal of Social Issues, 31(3), 137-149. doi:10.1111/j.1540-4560.1975.tb01000.x 
DRUŠ. ISTRAŽ. ZAGREB GOD. 23 (2014), BR. 4, STR. 615-637

JAKOPEC, A., SUŠANJ, Z.: EFFECTS OF..
Donovan, M. A., Drasgow, F., \& Munson, L. J. (1998). The Perceptions of Fair Interpersonal Treatment scale: Development and validation of a measure of interpersonal treatment in the workplace. Journal of Applied Psychology, 83(5), 683-692. doi:10.1037/0021-9010.83.5.683

Edwards, J. R. (1994). Regression analysis as an alternative to difference scores. Journal of Management, 20(3), 683-689. doi:10.1016/01492063(94)90011-6

Epitropaki, O. (2013). A multi-level investigation of psychological contract breach and organizational identification through the lens of perceived organizational membership: Testing a moderated-mediated model. Journal of Organizational Behavior, 34(1), 65-86. doi:10.1002/job.1793

Folger, R., \& Konovsky, M. A. (1989). Effects of procedural and distributive justice on reactions to pay raise decisions. Academy of $\mathrm{Ma}$ nagement Journal, 32(1), 115-130. doi:10.2307/256422

Greenberg, J. (2011). Organizational justice: The dynamics of fairness in the workplace. In S. Zedeck (Ed.), APA handbook of industrial and organizational psychology (pp. 271-327). Washington, DC: American Psychological Association.

Gregson, T. (1987). Factor analysis of a multiple-choice format for job satisfaction. Psychological Reports, 61(3), 747-750. doi:10.2466/pr0.1987. 61.3.747

Hartmann, F., \& Slapničar, S. (2012). Pay fairness and intrinsic motivation: The role of pay transparency. The International Journal of $\mathrm{Hu}$ man Resource Management, 23(20), 4283-4300. doi:10.1080/09585192.20 12.664962

Jakopec, A., \& Sušanj, Z. (2014). Provjera dimenzionalnosti konstrukta pravednosti u organizacijskom kontekstu (Verifying the dimensionality of justice construct in organizational context). Psihologijske teme, 23(2), 305-325.

Johnson, J. W., \& Ferstl, K. L. (1999). The effects of interrater and self-other agreement on performance improvement following upward feedback. Personnel Psychology, 52(2), 271-303. doi:10.1111/j.1744-6570. 1999.tb00162.x

Karriker, J. H., \& Williams, M. L. (2009). Organizational justice and organizational citizenship behavior: A mediated multifoci model. Journal of Management, 35(1), 112-135. doi:10.1177/0149206307309265

Konovsky, M. A., \& Pugh, S. D. (1994). Citizenship behavior and social exchange. Academy of Management Journal, 37(3), 656-669. doi: $10.2307 / 256704$

Lavelle, J. J., Rupp, D. E., \& Brockner, J. (2007). Taking a multifoci approach to the study of justice, social exchange, and citizenship behavior: The target similarity model. Journal of Management, 33(6), 841-866. doi:10.1177/0149206307307635

Lavelle, J., Rupp, D., Manegold, J. G., \& Thornton, M. (in press). Multifoci justice and target similarity: Emerging research and extensions. In M. Ambrose, \& R. Cropanzano (Eds.), The Oxford handbook of justice in work organizations. Oxford: Oxford University Press.

LePine, J. A., Erez, A., \& Johnson, D. E. (2002). The nature and dimensionality of organizational citizenship behavior: A critical review 
DRUŠ. ISTRAŽ. ZAGREB GOD. 23 (2014), BR. 4 STR. $615-637$

JAKOPEC, A., SUŠANJ, Z. EFFECTS OF... and meta-analysis. Journal of Applied Psychology, 87(1), 52-65. doi:10. 1037/0021-9010.87.1.52

Leventhal, G. S. (1976). The distribution of rewards and resources in groups and organizations. Advances in Experimental Social Psychology, 9, 91-131. doi:10.1016/S0065-2601(08)60059-3

Liao, H., \& Rupp, D. E. (2005). The impact of justice climate and justice orientation on work outcomes: A cross-level multifoci framework. Journal of Applied Psychology, 90(2), 242-256. doi:10.1037/00219010.90.2.242

Locke, E. A. (1969). What is job satisfaction? Organizational Behavior and Human Performance, 4(4), 309-336. doi:10.1016/0030-5073(69)90013-0

Marlowe, H. A., \& Nyhan, R. C. (1992). The Psychometric Properties of the Organizational Trust Inventory. Unpublished manuscript. Gainesville, FL: University of Florida, Institute of Higher Education.

Masterson, S. S., Lewis, K., Goldman, B. M., \& Taylor, M. S. (2000). Integrating justice and social exchange: The differing effects of fair procedures and treatment on work relationships. Academy of Management Journal, 43(4), 738-748. doi:10.2307/1556364

McDowall, A., \& Fletcher, C. (2004). Employee development: An organizational justice perspective. Personnel Review, 33(1), 8-29. doi:10. 1108/00483480410510606

Morrison, E. W., \& Robinson, S. L. (1997). When employees feel betrayed: A model of how psychological contract violation develops. Academy of Management Review, 22(1), 226-256.

Organ, D. W. (1997). Organizational citizenship behavior: It's construct clean-up time. Human Performance, 10(2), 85-97. doi:10.1207/ s15327043hup1002_2

Podsakoff, P. M., MacKenzie, S. B., Lee, J. Y., \& Podsakoff, N. P. (2003). Common method biases in behavioral research: A critical review of the literature and recommended remedies. Journal of Applied Psychology, 88(5), 879-903. doi:10.1037/0021-9010.88.5.879

Price, K. H., Lavelle, J. J., Henley, A. B., Cocchiara, F. K., \& Buchanan, F. R. (2006). Judging the fairness of voice-based participation across multiple and interrelated stages of decision making. Organizational Behavior and Human Decision Processes, 99(2), 212-226. doi:10.1016/ j.obhdp.2005.10.005

Robinson, S. L., Kraatz, M. S., \& Rousseau, D. M. (1994). Changing obligations and the psychological contract: A longitudinal study. Academy of Management Journal, 37(1), 137-152. doi:10.2307/256773

Robinson, S. L., \& Morrison, E. W. (1995). Psychological contracts and OCB: The effect of unfulfilled obligations on civic virtue behavior. Journal of Organizational Behavior, 16(3), 289-298. doi:10.1002/job.40 30160309

Rousseau, D. M., Sitkin, S. B., Burt, R. S., \& Camerer, C. (1998). Not so different after all: A cross-discipline view of trust. Academy of Management Review, 23(3), 393-404. doi:10.5465/AMR.1998.926617

Rupp, D. E., Bashshur, M., \& Liao, H. (2007). Justice climate past, present, and future: Models of structure and emergence. Research in Multi Level Issues, 6, 357-396. doi:10.1016/S1475-9144(07)06017-1 
DRUŠ. ISTRAŽ. ZAGREB GOD. 23 (2014), BR. 4, STR. 615-637

JAKOPEC, A., SUŠANJ, Z.: EFFECTS OF..
Rupp, D. E., \& Cropanzano, R. (2002). The mediating effects of social exchange relationships in predicting workplace outcomes from multifoci organizational justice. Organizational Behavior and Human Decision Processes, 89(1), 925-946. doi:10.1016/S0749-5978(02)00036-5

Rupp, D. E., McCance, A. S., Spencer, S., \& Sonntag, K. (2008). Customer (in)justice and emotional labor: The role of perspective taking, anger, and emotional regulation. Journal of Management, 34(5), 903-924. doi:10.1177/0149206307309261

Rupp, D. E., \& Paddock, E. L. (2010). From justice events to justice climate: A multi-level temporal model of information aggregation and judgment. Research on Managing Groups and Teams, 13, 245-273. doi:10. 1108/S1534-0856(2010)0000013012

Rupp, D. E., Shao, R., Jones, K. S., \& Liao, H. (2014). The utility of a multifoci approach to the study of organizational justice: A meta-analytic investigation into the consideration of normative rules, moral accountability, bandwidth-fidelity, and social exchange. Organizational Behavior and Human Decision Processes, 123(2), 159-185. doi:10.1016/ j.obhdp.2013.10.011

Shanock, L. R., Baran, B. E., Gentry, W. A., Pattison, S. C., \& Heggestad, E. D. (2014). Erratum to: Polynomial regression with response surface analysis: A powerful approach for examining moderation and overcoming limitations of difference scores. Journal of Business and Psychology, 29(1), 161. doi:10.1007/s10869-013-9317-6

Shanock, L. R., Baran, B. E., Gentry, W. A., Pattison, S. C., \& Heggestad, E. D. (2010). Polynomial regression with response surface analysis: A powerful approach for examining moderation and overcoming limitations of difference scores. Journal of Business and Psychology, 25(4), 543-554. doi:10.1007/s10869-010-9183-4

Skarlicki, D. P., \& Folger, R. (1997). Retaliation in the workplace: The roles of distributive, procedural, and interactional justice. Journal of Applied Psychology, 82(3), 434-443. doi:10.1037/0021-9010.82.3.434

Stapel, D. A., \& Koomen, W. (2001). The impact of interpretation versus comparison mindsets on knowledge accessibility effects. Journal of Experimental Social Psychology, 37(2), 134-149. doi:10.1006/jesp.2000.1440

Turnley, W. H., Bolino, M. C., Lester, S. W., \& Bloodgood, J. M. (2003). The impact of psychological contract fulfillment on the performance of in-role and organizational citizenship behaviors. Journal of Management, 29(2), 187-206. doi:10.1177/014920630302900204

Tyler, T., Degoey, P., \& Smith, H. (1996). Understanding why the justice of group procedures matters: A test of the psychological dynamics of the group-value model. Journal of Personality and Social Psychology, 70(5), 913-930. doi:10.1037/0022-3514.70.5.913

Van den Bos, K. (2002). Assimilation and contrast in organizational justice: The role of primed mindsets in the psychology of the fair process effect. Organizational Behavior and Human Decision Processes, 89(1), 866-880. doi:10.1016/S0749-5978(02)00033-X

Wang, M., Liao, H., Zhan, Y., \& Shi, J. (2011). Daily customer mistreatment and employee sabotage against customers: Examining emotion and resource perspectives. Academy of Management Journal, 54(2), 312-334. doi:10.5465/AMJ.2011.60263093 
DRUŠ. ISTRAŽ. ZAGREB GOD. 23 (2014), BR. 4 STR. $615-637$

JAKOPEC, A., SUŠANJ, Z.: EFFECTS OF..
Wanous, J. P., Stumpf, S. A., \& Bedrosian, H. (1979). Job survival of new employees. Personnel Psychology, 32(4), 651-662. doi:10.1111/j. 1744-6570.1979.tb02338.x

Westbrook, R. A., \& Reilly, M. D. (1983). Value-percept disparity: An alternative to the disconfirmation of expectations theory of consumer satisfaction. In R. P. Bagozzi, \& A. M. Tybout (Eds.), Advances in consumer research (Volume 10, pp. 256-261). Ann Abor: Association for Consumer Research.

Williams, L. J., \& Anderson, S. E. (1991). Job satisfaction and organizational commitment as predictors of organizational citizenship and in-role behaviors. Journal of Management, 17(3), 601-617. doi:10.1177/ 014920639101700305

\section{Učinci (ne)usklađenosti pravednosti rukovoditelja i organizaciiske pravednosti}

Ana JAKOPEC

Filozofski fakultet, Osijek

Zoran SUŠANJ

Filozofski fakultet, Rijeka

Ovim su radom provjereni interakcijski učinci pravednosti rukovoditelja i organizacijske pravednosti na ishode usmjerene na rukovoditelja (zadovoljstvo rukovodstvom i povjerenje u rukovodstvo) i organizaciju (percipirano ispunjenje psihološkog ugovora i odgovorna organizacijska ponašanja). Rezultati polinomne regresije i metode odzivne površine potvrđuju da su pozitivni interakcijski učinci izvora pravednosti na sve mjerene ishode najizraženiji u situaciji kada zaposlenici percipiraju tretman od obaju izvora pravednim. Ipak, učinci stupnja i smjera neusklađenosti variraju, ovisno o mjerenom ishodu i vrsti pravednosti. Ako se jedan izvor percipira pravednim, a drugi nepravednim, to najčešće rezultira negativnijim ishodima $u$ odnosu na situaciju kada su oba izvora percipirana nepravednim, neovisno o sličnosti izvora i mete. Dobiveni rezultati naglašavaju potrebu za povećanjem usklađenosti organizacijskih sustava i aktivnosti rukovoditelja u procesima upravlianja ljudskim potencijalima.

Ključne riječi: neusklađenost raznih izvora pravednosti, distributivna, proceduralna i interakcijska pravednost 